\title{
K PÔVODU KYJEVSKÝCH LISTOV Z ONOMASTICKÉHO HLADISKA
}

\section{On the Origin of the Kiev Leaflets from the Onomastic Point of View}

\author{
Martin Pukanec
}

DOI: $10.17846 /$ CL.2018.11.2.78-86

\begin{abstract}
PUKANEC, Martin. On the Origin of the Kiev Leaflets from the Onomastic Point of View. This paper seeks to throw new light on the origin of the Kiev Leaflets by comparing the toponyms in Pannonia and the toponyms in the northern Tisa region. In the northern Tisa region, the Uh-Sotak dialect has been spoken. This dialect seems to be very archaic and able to preserve old linguistic features, including accent. The accent of the Sotak dialect of Koromla, recorded by O. Broch in 1899, is very similar, maybe identical to one in the Kiev Leaflets. Moreover, in the Uh-Sotak dialect we can find all the important phonetic and morphological features of the Kiev Leaflets, such as ${ }^{\star} t j / k t>c,{ }^{*} d j>(d) z,{ }^{*} s k /{ }^{*} s t j>\check{s} \check{c}$, ${ }^{*} d l>l$, epenthetic $l$, roT-, dobrajego $>$ dobraego $>$ dobraago $>$ dobrago, as well as ${ }^{*} j_{b-}>{ }^{*} i$ and then primi/primi, I sg. m. - - $m$ mo/-emb, D sg. teb-, G pl. f. -ach, maybe *voch- > vbs-, and no G sg., A pl. f. of ja-stems -ě. The toponyms of the northern Tisa region seem to be in accordance with the dialect of the Kiev Leaflets, too.

Keywords: Slavic accentology, Slavic languages, Slovak language, Slovak dialectology, Old Church Slavonic, Kiev Leaflets, onomastics

Abstrakt: PUKANEC, Martin. K pôvodu Kyjevských listov z onomastického hladiska. Cielom tohto článku je vniest nové svetlo do otázky pôvodu Kyjevských listov porovnaním toponým v Panónii s toponymami v severnom Potisí. V severnom Potisí sa hovorí užsko-sotáckymi nárečiami. Tento dialekt sa javí byt vel’mi archaický a schopný zachovávat prastaré jazykové črty vrátane prízvuku. Prízvuk sotáckeho nárečia obce Koromla, zaznamenaný O. Brochom v roku 1899, je vel’mi podobný prízvuku v Kyjevských listoch, ba možno je s ním identický. V užsko-sotáckych nárečiach môžeme okrem toho nájsț všetky dôležité hláskoslovné a tvaroslovné znaky Kyjevský listov, ako je ${ }^{\star} t j / k t>c,{ }^{\star} d j>(d) z,{ }^{*} s k{ }^{*} s t j>\check{s} \check{c},{ }^{\star} d l>l$, epentetické $l$, roT-, dobrajego $>$ dobraego $>$ dobraago $>$ dobrago, tak aj ${ }^{\star} j b->{ }^{*} i$ - a následne primi/primi, I sg. m. -rmb/-emb, D sg. teb-, G pl. f. -ach, možno *vbch- > vbs- a neprítomnost’ -ě v G sg., A pl. f. ja-kmeňov. Toponymá v severnom Potisí sa s nárečím Kyjevských listov rovnako zdajú byt v súlade.
\end{abstract}

Klúčové slová: slovanská akcentológia, slovanské jazyky, slovenskýjazyk, slovenská dialektológia, staroslovienčina, Kyjevské listy, onomastika

Ked’ uvažujeme o pôvode Kyjevských listov, môžeme ich považovat’ za česko-slovenskú či vel'komoravskú redakciu prastaroslovienčiny, resp. klasickej staroslovienčiny, čo je do velkej miery opodstatnené. Táto starobylá hlaholská písomnost’ však neprešla bulharsko-macedónskym jazykovým prostredím, takže aj preto môžeme jej pôvod hladat̉ tiež v nejakom konkrétnom nárečí praslovančiny (pre diskusiu o tomto pozri napr. Schaeken 1987, 104-121). Najväčšou autoritou, čo sa v tomto ohlade vyjadrila pozitívne, je F. Kortlandt (1980, 1-3), podla ktorého „die Sprache 
der Kiever Blätter die Quantitäten des Serbokroatischen, in gewissen Fällen aber die Akzentstelle des Slowakischen aufweist“. Prízvuk na prvej slabike zložitých viacslabičných výrazov v Kyjevských listoch ako vb́semogzî̀, vb́semogȳi, dóstoini, dóstoiny ap. nie je však len slovenský, ale západoslovanský, a neskracovanie cirkumflexovej intonácie v dvojslabičných slovách tiež nie je evidentným srbochorvátskym prvkom. Ak toto platí pre výraz v Kyjevských listoch plěnz, staršia slovenčina, ba slovenčina dodnes má aj plien a sloveso je plienit, teda s dĺžkou. Ak povedané platí rovnako pre adjektívum $s v \bar{e} t z \hat{\imath}$, tak tu tiež treba uviest', že čeština a slovenčina majú prinajmenšom popri odvodeninách s krátkostou i odvodeniny s dĺžkou. F. Kortlandt v každom prípade umiestnil pôvod Kyjevských listov do Panónie, čo je logické, kedže pamiatka má južnoslovanské i západoslovanské jazykové znaky.

Spomedzi slovanských dialektov, ktoré nevymreli, však nárečiu Kyjevských listov najviac zodpovedajú užsko-sotácke nárečia, ktoré sú archaickým okrajom východného regiónu východnej slovenčiny (porov. Kováčová 2015, 76), čo susedí s nezápadoslovanskými jazykmi. Majú $c<{ }^{\star} t j /$ $k t,(d) z<{ }^{\star} d j, \check{s} \check{c}<{ }^{\star} s k$ a ${ }^{\star} s t j$, podla S. Czambela $(1906,123) v b s-$ a nie $v b \check{s}-$, zriedkavo ${ }^{\star} d l>l$, západoslovanskú metatézu s roT- (variantnost' s raT-ukazuje onymia), kontrakciu typu dobrajego $>$ dobraego $>$ dobraago $>$ dobrago (asimilácia či analógia bude aj v dnešnom sotáckom či širšie východoslovenskom dobroho), zrejme mohli mat' a ojedinelo majú epentetické $l$ ', mali začiatočné ${ }^{\star} i-\mathrm{z}^{\star} j b$ - a následne prìmi/primi, I sg. tvrdých maskulín -əmb a asi -emb mäkkých, v paradigmách mäkkých substantív nemuseli mat'-ě, lež i -ę (majú -y), D sg. od ty majú teb-, G pl. od sila zas siloch/silach a koreň cir- pre „chrám, cirkev“. Sotácke nárečia, ktoré v hláskosloví takmer udržiavajú stav, aký sa rekonštruuje pre najstaršiu slovenčinu, môžu mat navyše potenciál udržiavat naprieč tisícročím aj prízvuk, podobne ako je to v prípade pomoranskej slovinčiny či čakavčiny. Tento bol v sotáckej Koromli v 19. storočí (pozri Broch 1899) vel’mi podobný prízvuku v Kyjevských listoch: tvary osobných zámen majú prízvuk na prvej slabike, tvary zámena *vbchmajú prízvuk na predposlednej slabike, tvary slovesa byt majú prízvuk na prvej slabike, tvary slovies z paradigmy AP (b) majú prízvuk na prvej slabike, tvary slovies s tematickou morfémou -ova- majú prízvuk na jej druhej slabike, tvary imperatívu atematických slovies majú prízvuk na prvej slabike koreňa, tvary imperatívu tematických slovies mávajú prízvuk na poslednej slabike, tvary $a$ - a $o$-kmeňov z paradigmy AP (a) majú prízvuk na prvej slabike, tvary pôvodných $s$-kmeňov z paradigmy AP (c) mali prízvuk v G sg. na prvej slabike atd’, pričom niektoré zámená či imperatívy sú silným akcentologickým argumentom spájania Kyjevských listov so sotáckou oblastou (pozri viac Pukanec 2017).

Užsko-sotácke nárečia nemôžu byt podla nás ničím iným ako pozostatkom praslovanského nárečia Východných Obodritov, ktorých J. Steinhübel volá sugestívne (a nepresne) južní Obodriti, lebo ich podla ich druhého mena Praedenecenti podobne ako D. Třeštík považuje za Zbojníkov, a teda mu nič nebráni klásț ich sídla až na dolnú Tisu (pozri Steinhübel 2004, 62; Třeštík 2001, 103). Týmto zrejme obidvaja narážajú na latinské apelatíva praeda „korist" a necāre „zabíjat“. Geografovi Osterabtrezi, čiže Východní Obodriti, nie južní (sic!), sa zvyknú klást’ na strednú a dolnú Tisu (porov. napr. MMFH I 1966, 51), ale v prospech toho, že boli skôr niekde v severnom Potisí a že boli východnými, resp. juhovýchodnými susedmi druhých naddunajských Moravanov (Merehanov) Bavorského Geografa svedčia minimálne tri argumenty (pozri viac aspoň Pukanec 2013, 30-33):

1. Hned' po Moravanoch ich nespomína len Bavorský Geograf (po Merehanoch), ale i Annales Regni Francorum: „orientalium Sclavorum, id est Abodritorum, Soraborum, Wilzorum, Beheimorum, Marvanorum, Praedenecentorum“ (MMFH I 1966, 50), pričom aj tieto výslovne zdôrazňujú, že sú to v relatívnom ponímaní východní (sic!), nie južní Slovania;

2. etnonymum Obodriti znamenalo „bývajúci okolo Bodrogu“, pretože slovenské hydronymum Bodrog, ktoré pomenovávalo aj celú Ondavu, získalo príponu -og určite až prostredníctvom 
mad’arčiny (pozri Lutterer - Majtán - Šrámek 1982, 55-56): pomenovanie Obodriti bolo tak typicky vytvoreným slovanským etnonymom typu predložka + toponymum (tak Polabi boli „pri Labe“, Pomorani „pri Mori“, Posuljani „pri Sule“, Poršani „pri Rose“, Zachlumi „za Chlumom“, Zagozd(i) „za Hvozdom“, Črezpeňani „cez Penu“ a pod.);

3. slovo vulgo vo vete "Abodritorum, qui vulgo Praedenecenti vocantur“ (MMFH I 1966, 51) znamená „nie latinsky, ale v nejakom ludovom jazyku“ (porov. Haefs 2004, 179) a slovanské etnonymum Praedenecenti, Praedevecenti, Praedenescenti (pozri Šafárik 1863, 225) a sídelný priestor jeho nositelov musí byt vlastne odrazom sídiel dáckeho kmeňa, ktorý sa u Ptolemaia nazýva Predavensioi (takto boli Česi volaní ako keltskí Bójovia), pričom týchto sám Ptolemaios kladie severnejšie ako Kotínov, ktorých umiestňuje do severovýchodnej časti Hornej Panónie (pozri Hoops 2003, 470; Mócsy 1974, 57).

Cielom tohto článku je porovnat toponymiu Panónskeho kniežatstva, ktoré pri hladaní pôvodu Kyjevských listov uprednostňuje F. Kortlandt a viacerí d’alší, s toponymiou severného Potisia, ktorú vzhladom na podobné jazykové črty užsko-sotáckych nárečí a nárečia Kyjevských listov musíme považovat za rovnako pravdepodobnú, ak nie pravdepodobnejšiu hypotézu miesta pôvodu tejto najstaršej hlaholskej pamiatky. Pri tomto onomastickom porovnávaní sa budeme opierat’ predovšetkým o výskumy Jána Stanislava a všímat si iba hláskoslovne relevantné názvy spred roku 1526, po ktorom sa na danom území výraznejšie menilo osídlenie.

V niekdajšej Panónii, v sverozápadnom kúte dnešného Madarska, na juh od Prešporskej župy, sa nachádza Mošonská župa a na juh od nej Šopronská župa. Tieto boli dlhé stáročia osídlené Slovanmi. Napríklad na východnom povodí rieky Ráby je doložených viacero toponým, ktoré svedčia o slovenskom jazyku (pozri aspoň Stanislav 1956, 152-153). Zo starších praslovanských javov, ktoré sa týkajú Kyjevských listov, môžeme spomenút aspoň to, že za praslovanské * dj býva $d z$, ktoré sa zapisuje v madarčine s dentálnym elementom: ojkonymum v Mošonskej župe Szögye, doložené od 14. storočia, musí byt zo Sedza (pozri Stanislav 1999, 143; Stanislav 2004, 402) a ojkonymum Pomogy (Pamhagen) v Mošonskej župe, ako i Pomogy (dnešný Zillingtal) v Šopronskej župe, obe doložené už v 13. storočí (pozri Stanislav 1999, 145; Stanislav 2004, 359), sú zas $z$ Pomedza. Slovinčina má naproti tomu namiesto * dj kontinuant $j$ a hoci do úvahy čisto teoreticky pripadá ešte pol'ské $d z$ a chorvátske $d$, geograficky sa o nich uvažovat' nedá. Pri Neziderskom jazere sa nachádzal Chythtwan 1299, Chydwand 1410, Chythuand 1411 atd., čo bude najskôr zo *Ščitovan $(y)$ so západoslovanskou skupinou šč, ktorá je aj v Kyjevských listoch, lež aj s chýbajúcim l’epentetickým, tak má srbochorvátčina napríklad Križovljane (pozri Stanislav 2004, 110), a toto $v$ Kyjevských listoch máme.

V Šopronskej župe sa nachádzala dnes nemecká obec Stoob, mad’arsky Csáva, je doložená už v 13. storočí viackrát ako Chawa, čo bude zo Ščava so skupinou šč (pozri Stanislav 2004, 9394), aká je v Kyjevských listoch. V 13. storočí je doložená osada Névegy (na území dnešnej obce Fertőszentmiklós) z Nevidza s dz (pozri Stanislav 1999, 148). V župe sa na rieke Rábe nachádza západoslovanské ojkonymum Sobor [š-], doložené v roku 1314, zo slova Vbšeborz > V̌̌ebor > Šebor, lebo južní Slovania by mali $s$ (pozri Stanislav 1999, 152; Stanislav 2004, 435), pričom Kyjevské listy majú v tejto pozícii nevyhovujúce -s-. V juhozápadnej časti Šopronskej župy je podobne názov Gyalóka, doložený v roku 1308 (pozri Stanislav 2004, 172), po nemecky Jelwicken z Jelovbka, ktorý poukazuje na v zásade najmä južnoslovanské $l \mathrm{za}{ }^{*} d l$, a ojkonymum Gereblyén (čast̉ dnešnej obce Zsira), zapísané ako Garablyan 1319, 1323, ktoré obsahuje južnoslovanské epentetické l' (pozri Stanislav 1956, 152-153), pričom oba tieto javy sú aj v Kyjevských listoch.

Na samom západe Uhorska sa na juh od Šopronskej župy nachádzala Železná (Vašská) župa. V nej boli v blízkosti obcí Szombathely a Sárvár osady Szeleste [Selešte], v roku 1270 Zeleste (Stanislav 2004, 405), čo skupinou št < ${ }^{\star} s k j$ ukazuje na srbochorvátčinu, pričom Kyjevské listy majú šč. Za praslovanské *orlınikz bez akútu je tu ojkonymum Rolnik, doložené v roku 1388, toto 
nemôže byt južnoslovanské (Stanislav 2004, 388). To zrejme ani názov majetku Jákovcov Geregye, doložený 1437, čo je úplne pravidelný kontinuant Gradza s $d z<{ }^{\star} d j$ (pozri Stanislav 2004, 161). Od 13. storočia je známe ojkonymum, ktoré je doložené v roku 1218 ako Turpuch, 1314 Tyre buch, 1399 Trebech, 1424 Threbycz, Trebych, 1437 Trebuch, 1448 Terebicz, čo môže byt vari majetok Pribinovho velmoža Trěbica (pozri Stanislav 2004, 463-464), ktorého meno má západoslovanský sufix $-i c$, kde $c<{ }^{\star} t j$ ako $\mathrm{v}$ Kyjevských listoch, no najstaršie zápisy poukazujú jednoznačne skôr na srbochorvátske -ć, príp. slovinské -

So Železnou župou na juhu susedí Zalianska župa, na ktorej území sa nachádzalo centrum Panónskeho kniežatstva Pribinu a Kocela, ich hlavné sídlo bolo v dnešnom Zalaváre. Na vývin ${ }^{*} d j>d z$, resp. $d$, poukazuje názov Gerengye $\mathrm{z}{ }^{\star}$ Grędja, so zachovanou nosovkou, čiže starobylý, a typ Névegy < ${ }^{\star}$ Nevidja, zaznamenaný od 13. storočia (pozri Stanislav 2004, 311). Podobne tak názov Nyirád, zapísaný už v roku 1272 ako Nerrad, poukazuje svojím zápisom z roku 1454 Nyragh na slovenské $d z$ alebo srbochorvátske $d$; bolo by tu pôvodne potom ${ }^{*}$ Nerad-ja, resp. ${ }^{\star} N e r a d-j b$, k osobnému menu Nerad (pozri Stanislav 2004, 318). Názov Lengyel, Lengel 1019/1370, 1233, 1256, 1271 atd'. (pozri Stanislav 2004, 265) bude zo slovenského ${ }^{\star} \operatorname{Leqdzan(y),~príp.~zo~srbochorvát-~}$ činy, ktorej $d$ dáva $\mathrm{v}$ mad’arčine rovnaký výsledok. Iba západoslovanský môže byt však zrejme názov Vöczkönd, doložený od 15. storočia, k osobnému menu Vackon, ku ktorému patrí Václav $s c<{ }^{\star} t j$ (pozri Stanislav 1956, 156-157). Západoslovanské budú azda tiež pravdepodobné názvy pre rôzne Štitáre s palatalizovanou skupinou šč, ako je doložená v danom ojkonyme aj na začiatku 12. storočia pri Nitre: v Zalianskej župe je to obec a samota Chitary 1141 - 1161, od 14. storočia Chatar, dnes Csatár, d’alšia samota Csatár, zaznamenaná v roku 1137 ako Chiatarii a od 14. storočia ako Chatar, a vari i Letenye Chatar v zápise z roku 1366 (pozri Stanislav 2004, 93). Skupinu šč však môže mat aj čast' chorvátčiny. Južnoslovanské či stredoslovenské je $l<{ }^{*} d l$ v názve Kapolcs, doloženom od 11. storočia (pozri Stanislav 2004, 217), tak je i v Kyjevských listoch. V ojkonyme Szoboszló, doloženom už v roku 1270 ako Zobozlou, z antroponyma Soběslav vidíme naproti tomu potenciálny bohemizmus sobě (pozri Stanislav 1956, 155-157), čo nie je v súlade s jazykom Kyjevských listov, kde je často analogické tebě ako v slovenčine či u južných Slovanov. V súlade s Kyjevskými listami nie je celkom ani ojkonymum v blízkosti vŕšku Perjászló, ktoré je v župe doložené v roku 1265 ako villa Priazo, 1269 Preaszlef, 1272 Preazlo, čo musí byt' k antroponymu Prějaslav bez epentetického l', ktoré vidíme v analogickom ruskom Perejaslavlb (pozri Stanislav 2004, 372). Ďalší problém predstavuje dost̉ nejasný názov doložený v župe už v roku 1082 ako Scerente, 1275 Zerenche, tak aj v 14. storočí, pretože pochádza zrejme zo srbochorvátskeho ${ }^{\star S}$ Sęća (pozri Stanislav 2004, 410), kde by bolo ć za ${ }^{\star} t$, teda nie $c$, navyše je tu zachovaná nosovka, takže tento názov je starobylý a zásadný a odporuje Kyjevským listom.

S Balatonom susedí aj Šomodská župa, ktorá sa nachádzala na východ a juhovýchod od Zalianskej. V jej severnejšej časti vidíme ojkonymum Osztopán, zapísané v roku 1229 ako Oztupan, 1284, 1348 Ztupan, čo bude zo Stupan $(y)<{ }^{\star}$ stop-jan $\mathrm{k}{ }^{\star}$ stopa ,velká jama na polovanie zveri“, teda bez epentetického l' (pozri Stanislav 2004, 325). Na juhu župy sú však viaceré mená, ktoré poukazujú na epentetické l', ako je Lepled, doložený v roku 1269, z pôvodného Liple, so zmenou $i>e$, ktorá prebehla $\mathrm{v}$ mad’arčine $\mathrm{v} 12$. storočí, a s mad’arským deminutívnym sufixom $-d$ (pozri Stanislav 2004, 267), potom staré hydronymum Dumbul z roku 1268, kde vidíme nosovku, $\mathrm{z}^{\star} D Q b l b<{ }^{\star} D Q b+j b$ (Stanislav 2004, 144), a napokon vari i ojkonymum Ropoly, zaznamenané od 13. - 14. storočia ako Rupul; v obci sa navyše výslovne spomínajú Slovania (pozri Stanislav 1999, 187). Samota Döbrög svojimi zápismi v 15. storočí Debregh 1414, 1423, Debreregh 1415 atd'. poukazuje na dentálny element $\mathrm{v}$ koncovke slovanského kontinuantu pôvodného ${ }^{\star}$ Dobroradjo (pozri Stanislav 2004, 133), tak aj samota, ktorá je zaznamenaná už v roku 1346 ako Lytaragh, čo bude $\mathrm{z}^{\star}$ Lutoradj (Stanislav 2004, 495). V blízkosti dnešnej mad’arsko-chorvátskej hranice bola navyše Chovonya 1406, Chowanya 1473, Chawonya 1486, čo bude zo Ščaviňa s hláskovou skupinou 
šč (pozri Stanislav 2004, 94), takže sa môže zdat', že na juhu župy sa nachádzajú len javy, ktoré sú aj v Kyjevských listoch. Nie je to ale celkom tak. Máme tu totiž doložený názov Budich 1376, Bodych 1536, čo bude zo srbochorvátskeho osobného mena Budić (Stanislav 2004, 49), popri Predicz 1489, ktorý nemá zapísané ch indikujúce južnoslovanské ć či č (pozri Stanislav 2004, 372), takže bude asi západoslovanský. A dokonca aj na severe máme dodnes ojkonymum Andocs, ktoré poukazuje na palatalizáciu neprítomnú v Kyjevských listoch. Zapísané je v roku 1321 ako Onduch, 1390 Andoch atd'. a bude najskôr z Andić (pozri Stanislav 2004, 9), takže ani tu nemožno počítat so západoslovanskou zmenou ${ }^{\star} t j>c$. So západoslovanským $c$ ale treba na druhej strane jednoznačne počítat v zjavne starobylom názve Vinceslav 1193, ktoré je zo západoslovanského Vęceslavz (pozri Stanislav 1999, 186), a západoslovanská palatalizácia ${ }^{*} j>c$ je vidiet’ $v$ rovnako starobylom oronyme Zselic, de Siliso 1061, 1257 atd., silva Selez 1083 - 1095 ap., čo je z osobného mena Žilic, ktorého nositel' bol aj Pribinovým vel'možom.

Ďalej na juhovýchod hraničila so Šomodskou Baranská župa. Z nej poznáme starý názov s nosovkou Kyslengeld z roku 1474, Lengyel 1511, čo bude naisto $\mathrm{z}{ }^{\star}$ Lędjan(y) (pozri Stanislav 2004, 265), takže so slovanským kontinuantom s dentálnym elementom za ${ }^{\star} d j$, ako je hypoteticky i v Kyjevských listoch, ale nemusí to byt' slovenské $d z$. Tento element má asi tiež zaniknutá Burgungya 1397 z ${ }^{\star}$ Burgund-ja (pozri Stanislav 2004, 78) a Nyvig 1015 - 1158, Nimugh, Nimeg z Nevidja (Stanislav 1999, 196). Majetok v juhovýchodnej časti župy Razlou, Razlo 1330, Razlo 1425, 1470, 1471, 1481 z pôvodného Raslav má v názve zrejme stredoslovenské a južnoslovanské ra- (pozri Stanislav 2004, 382), ktoré je aj v Kyjevských listoch. Názov zaniknutého majetku Zunduch 1330 poukazuje azda na pôvodné slovanské Sodić (pozri Stanislav 2004, 421) s južnoslovanským ć za ${ }^{\star} t j$, čo by ale v súlade s Kyjevskými listami, samozrejme, nebolo, navyše dôležité je, že názov môže byt' starobylý, pretože v ňom vidíme nosovku. Zdá sa, že pri hladaní miesta pôvodu Kyjevských listov je Baranská župa už príliš na juhu, tak to aspoň naznačuje aj další zásadný, velmi starobylý názov s nosovkou Venche 1370, Venthye 1417, 1481 (Stanislav 1999, 196), ktoré bude $\mathrm{z}{ }^{\star} V e ̨ c ́ a<{ }^{\star} V e ̨ t j a$, teda s tým istým nevyhovujúcim kontinuantom.

Ked’ teda pôjdeme z Baranskej župy na sever, vstúpime do Tolnianskej župy. Niekde na hranici týchto dvoch žúp bol biskupský majetok Trochan 1391, Thorosthyan 1439 z ${ }^{*}$ Troščan(y) s palatalizovanou hláskovou skupinou šč (pozri Stanislav 2004, 49). Túto vidíme aj v názve Kusthan 1403,

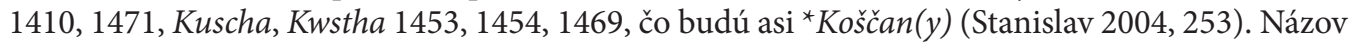
Lengyel, Lengel 1322 (Stanislav 2004, 265), poukazuje na ${ }^{\star}$ Lędjan(y) so slovanským kontinuantom s dentálnym elementom za ${ }^{\star} d j$, čo nemusí byt' len slovenské $d z$, lež aj srbochorvátske $d$. Zaniknutá osada Göszle 1305, Gözle 1455 by vzhladom na pol'ské Gozdlino mohla poukazovat na praslovanské východisko *Gozdla (Stanislav 1999, 202) a zmenu $d l>l$. Onymá v tejto župe teda neprotirečia jazyku Kyjevských listov, ale ani jasnejšie neukazujú potenciálnu hranicu medzi strednou slovenčinou a srbčinou a chorvátčinou.

Ďalej na sever je Belehradská župa s centrom v Stoličnom Belehrade (dnes Székesfehérvár), ktorá je na západ a severozápad od Balatonu a susedí z juhu s Komárňanskou župou. Belehradská župa je síce rozsiahla, ale pre svoj močaristý terén je pomerne riedko osídlená. Relevantné toponymá pre jazyk Kyjevských listov v nej často nenachádzame. Môžeme spomenút aspoň zaniknutý Chathar 1285, čo bude zo ^Ščitar-, Chygler 1397, 1436 atd', ktoré by mohlo byt zo ^Ščigla (pozri Stanislav 2004, 108, 112), a potom Meed 1298, možno z ${ }^{\star} M e d z(a)>$ Mégy > Méd, teda s potenciálnou zmenou ${ }^{\star} d j>d z$, ostatné zaujímavé názvy nie sú doložené v stredoveku (porov. Stanislav 1999, 206-212), takže ich opomíname. Na slovenské územie dalej na sever nemá zmysel vstupovat, pretože v analyzovanej pamiatke sú jazykové črty, ktorých v západnej a strednej slovenčine evidentne niet a nebolo, ale môžeme sa vydat na východ. Predtým však ešte treba spomenút Vesprímsku župu, ktorá je na sever od Balatonu a severovýchod od Zalianskej, kde 
malo byt' centrum Pribinovho a Kocelovho kniežatstva. Ďalej na sever od Vesprímskej a na juh od Prešporskej je menšia Rábska župa.

Vesprímska župa je zaujímavá najmä z hladiska výskytu epentetického $l$ '. Z osobného mena ${ }^{*}$ Neostopjo pochádza zrejme názov Nuztupe 1086/13. stor., Nuztup 1135, 1204 - 1235, 1258, Noztuph 1332 atd', čiže bez epentetického l'(pozri Stanislav 2004, 312-314), ale aj bez zachovanej nosovky. Zásadnejší je preto $\mathrm{v}$ každom prípade názov Koromla, kedže táto má v stredovekých zápisoch nosovku zachovanú: Kurumpla 1364, Koromla 1404, Korompla 1427, Koromplya 1480 atd., ktorý bude z ${ }^{\star}$ Kropla s epentetickým l; na Slovenskej zemi bola naproti tomu v Prešporskej župe Krupá - prvý zápis má ešte nosovku: Crumba 1113 (pozri Stanislav 2004, 244). Daný zápis ale môže vari byt’ i sekundárny, dovezený z užsko-sotáckej oblasti, príp. to môže byt naopak. V župe sa nachádzal aj Chatar 1233, iný Chatar 1240 a ešte aj nejaká Csatár puszta z roku 1491, ktoré sú zo ${ }^{\star S ̌ c ̌ i t a r-~(p o z r i ~ S t a n i s l a v ~ 2004, ~ 92-93) ~ s o ~ s k u p i n o u ~ s ̌ c ̌, ~ a k o ~ j e ~ v ~ K y j e v s k y ́ c h ~ l i s t o c h . ~ N a ~ t u ́ t o ~ a z d a ~}$ poukazuje aj ojkonymum Chygle 1275, Chigla 1340, Chigle 1439, ktoré by mohlo byt zo ${ }^{*}$ Šcigla, čo platí aj pre názov osady na brehu Balatonu Chygler z roku 1478 (pozri Stanislav 2004, 109, 111112). V Rábskej župe je dôležité spomenút Chytwan 1278, Chichwan 1325, Chytwand 1400, 1415, 1473, 1476, 1480 pre dnešný Csikvánd, pretože je najskôr zo *Ščitovan(y), kde je palatalizovaná skupina $\check{s} c ̌$ (pozri Stanislav 2004, 110). Sú tu aj dve lokality Péc k ${ }^{\star}$ pektb, ktoré je aj východiskom ojkonyma Pešt, kde vidíme bulharskú formu. J. Stanislav sa nazdáva, že Péc je západoslovanský tvar, ale pôvodne tam bolo asi srbské a chorvátske ć alebo slovinské $c$, ako ukazujú zápisy spred 15. storočia Pech 1240, Kyspeech 1367 a Peech 1373 (pozri Stanislav 2004, 341).

Takto by sa dala približne opísat onymia územia bývalého Panónskeho kniežatstva Pribinu a Kocela a jeho okolia. Z hladiska jazykových znakov Kyjevských listov nie je teda tento región onomasticky úplne presvedčivý, hoci niektoré jeho oblasti naznačujú možnú spojitost's jazykom Kyjevských listov vo väčšej miere, takto azda pár dokladmi napríklad Tolnianska a Vesprímska župa, pričom Vesprímske biskupstvo bolo prvým uhorským biskupstvom, takže to nie je irelevantné. Onymia tejto župy je v súlade s hlaholskou pamiatkou viac ako susednej Zalianskej, kde sa nachádzalo centrum Panónskeho kniežatstva Pribinu a Kocel’a. O niečo presvedčivejší celkový onomastický obraz ako v Panónii vari nájdeme, ked'sa vydáme d’alej na severovýchod do severného Potisia, kde mali sídla pravdepodobní východní susedia Moravanov Východní Obodriti.

Už vo významnom pomenovaní Zemplína sa možno skrýva epentetické l'. Názov jednej z najstarších uhorských žúp (komitátov) sa uvádza už od Anonyma, ako aj inde v 13. - 14. storočí Zemlin či Zemlyn, prípadne Zemlien, Zemlyen, Zemlun, Zemlum (pozri Stanislav 2004, 505), takže vylúčit tu epentetické l'nemožno. To platí aj pre samotu Zemlyn 1429, 1430, Zemlen 1470 v Abovskej župe, ktorá je na západ, resp. juhozápad od Zemplínskej, hoci tento názov môže byṫ i sekundárny (pozri Stanislav 2004, 506). Ďalej na východ je v Užskej župe Koromla: Koromlya 1393, Koromplya 1419, čo bude ${ }^{\star}$ Kropla s epentetickým l'(pozri Stanislav 2004, 244), pričom zápisy zachovávajú nosovku, takže sú starobylé a nepôjde tu určite o novší vplyv východoslovanských jazykov. To môže platit aj pre názov zo Satumarskej župy lacus Sarolyan, doložený od 12. storočia, ktorý bude ku *Žeravlans epentetickým l' (pozri Stanislav 2004, 512). V blízkosti východného Slovenska však nájdeme v severnom Potisí z hladiska Kyjevských listov aj dalšie zaujímavé črty.

Na juh od Zemplínskej župy je župa Sabločská. V nej sa v roku 1270 spomína Medwyge locus lutosus a to je z praslovanského *Medvědje (pozri Stanislav 2004, 289). Kedže $g$ v zápise reprezentuje najskôr mad’arské $g y$ [d], dentálny element poukazuje jednoznačne na kontinuant $d z$, lebo srbochorvátske $d$ je tu geograficky nepravdepodobné. V župe sa v 15. storočí spomína Magh, mad’arsky Magy, čo je možno Madz- k Mad-, a v roku 1329 Opogh, azda z ${ }^{\star}$ Opodz- k ${ }^{\star}$ podz; istejšia a starobylejšia (s nosovkou) je Kalenga, Kalanga z roku 1345, čo je z ${ }^{\star}$ Kolędja (pozri Stanislav 2004, 280, 10, 213). Ten istý jav sa nachádza v hornom Potisí v Berežskej župe, teda na východe od Užskej, v názve obce Batrad'na Ukrajine v blízkosti slovensko-mad’arskej hranice. V madarčine 
znie Bótrágy a zapisuje sa v rokoch 1270 a 1272 ako Bolterag a Boltrag. Východiskom je ${ }^{\star}$ Boltèradz k osobnému menu Boltěrad (pozri Stanislav 2004, 63); vo východnej slovančine by za * dj bolo ž. Zmenu * $d j>d z$ vidíme aj v mad’arskom názve potoka Zagyva v Abovskej župe: 1318 Zagoa, čo je aj hydronymum označujúce lavý prítok Tisy v Novohradskej, Hevešskej a Solnocko-jasovskej župe, doložené od 13. storočia, oboje je zo Sadzava < ${ }^{\star}$ Sadjava (pozri Stanislav 2004, 500). V Abovskej sa vyskytuje od stredoveku ojkonymum Goegch, Gogy 1272/1419, čo je zo slovanského ${ }^{\star}$ Godz so zmenou ${ }^{\star} d j>d z$, teda k antroponymu God (porov. Hodejov) + sufix -jb (pozri Stanislav 2004, 153), čo je starobylá tvorba. Dokladom zmeny ${ }^{\star} d j>d z$ sú aj dva názvy Lengyelfalva $\mathrm{k}{ }^{\star}$ Lędjan-, známe už zo stredoveku, jeden v Abovskej, druhý v Užskej župe (pozri Stanislav 2004, 265); $d z$ tu však môže byt’ pol'ské, kedže Lengyel znamená „Poliak“.

Na Tise ešte v Sabolčskej župe možno spomenút ojkonymum Vencsellő, 1067 Wensellev, ktoré je $\mathrm{z}^{\star}$ Vęceslav alebo Vęcilov, kde $c<{ }^{\star} t$, ako je v Kyjevských listoch, tak máme v župe aj Wense z roku

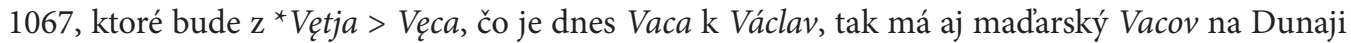
(pozri Stanislav 2004, 483-484). Na hornej Tise, v Ugočskej župe, je doložený v roku 1351 názov Wereecze, teda asi $\mathrm{z}{ }^{\star}$ Vèraca. Ako naznačuje slovinské Verače, aj tu bude azda $c$ za ${ }^{\star} t j$ (Stanislav 2004, 484). Zaujímavostou Potisia je, že sa v ňom rovnako ako v Kyjevských listoch nachádza rapopri ro- po metatéze likvíd, a to dokonca i v tom istom názve. V Abovskej župe bola Ráztokal Roztoka, doložená v 15. storočí ako Pastukafalva, t. j. Raztukafalva, ale aj Rosthoka a Bozthoka, t. j. Rozthoka (pozri Stanislav 2004, 383). Ešte podstatne východnejšie, v Satumarskej župe, je podobne hydronymum Rakyta, doložené z roku 1524 ako Rathka, dnes Rákta, ktoré zachováva ra-, ale aj Roztoka, v roku 1345 zaznamenaná ako Ruztica, ktorá má ro- (Stanislav 1956, 264-265); $\mathrm{v}$ župe sú aj ${ }^{*} \operatorname{Rozžal}(y)$, doložené v 14. storočí (Stanislav 2004, 389). V Zemplínskej župe vidíme v názve Rozvadze, madarsky Rozvágy, doložené v 14. storočí ako Rosvad, Rozvagh, Rozuagh, popri slovenskom $d z$ aj západoslovanské ro-, ktoré máme tiež v Abovskej župe v názve Rozpuch, Rozpwth, zloženom z predpony roz- < *orz- a koreňa put < ${ }^{*}$ potb "cesta“ (pozri Stanislav 2004, 390). V onymii oblasti nie je neznáma ani západoslovanská kontrakcia, tak má napríklad dnešný Levelek v Sabolčskej župe, t. j. v strede medzi Abovskou a Satumarskou, starobylý zápis Leveluky z roku 1067, hoci už s denazalizáciou, kde Levé (lúky) je stiahnuté z ${ }^{\star}$ Levyjě (pozri Stanislav 1956, 176-180). V povodí Bodrogu sa v Abovskej župe v roku 1483 spomína Haradyscha, čo je Hradišče so skupinou šč (pozri Stanislav 2004, 176); takýto typ názvu so šč i št je doložený dostatočne aj na stredovekom Zemplíne a Boršode (pozri Stanislav 2004, 189), ba skupina šč dokonca i na východe v Satumarskej župe v názve Gachal < ${ }^{\star}$ Goščani ku ${ }^{*}$ gostb, so zmenou $n>l$, a Hugacha z toho

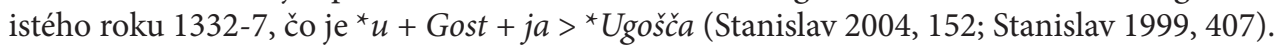

Všetka onymia oblasti ale nemusí byṫ v súlade s Kyjevskými listami. V Abovskej župe sa nachádza Sedlec, doložený v roku 1347 ako Zedlech, 1427 Sedlech ap., kde je zachované *dl (pozri Stanislav 2004, 402), ktoré je z hladiska Kyjevských listov nevyhovujúce. Samozrejme, je otázkou, či už ned’aleká stredoveká Seleška nemá * $d l>l$, alebo je z madarčiny, ako si myslí B. Varsik (1973, 219), takto sa aj východogemerská Silica uvádza v roku 1381 Zeliche s l, ale popri Zedlyche s $d l$ z roku 1386 (Varsik 1973, 304-305), takže pôvodný názov bol dvojtvar ${ }^{\star}$ Selice ${ }^{\star}$ Sedlice (porov. Stanislav 2004, 413). Tu treba podotknút, že prípady typu Sedlo proti Selo celkovo nie sú asi ideálnymi dokladmi izoglosy $d l \| l$, kedže praslovanské * selò musí byt príbuzné s celým radom germánskych výrazov s -l- (pozri Kroonen 2013, 424), ale predovšetkým i s litovským salà a lotyšským sala (pozri Derksen 2015, 387), a v praslovančine predpokladáme aj ${ }^{\star}$ sedzlo vo význame „sedadlo, sedlo“, čiže bez praslovanskej skupiny * $d l$ pred zánikom jerov. V Zemplínskej župe sa na juhu navyše nachádza obec Semjén: Semyan, Semyen 1332 - 1337, zo ^Šemjan(y), ktorej názov by mohol poukazovat na neprítomnost' epentetického l'(Stanislav 1999, 394). Tento názov je však bez l'rozšírený aj ovel’a južnejšie a jeho interpretácia je nejednoznačná (pozri Stanislav 2004, 431$432,436)$, takže preceňovat to nemožno. Je tu tiež v Užskej župe v roku 1271 zaznamenaná terra 
Zubuzlay, čo bude najskôr ${ }^{\star}$ Soběslav (pozri Stanislav 2004, 417), kde by bol zámenný tvar sobě, čo rovnako na prvý pohlad nie je v súlade s jazykom Kyjevských listov, v ktorých často vidíme analogické tebě, ako býva v spisovnej slovenčine či u južných Slovanov; faktom ale je, že nárečia na Zemplíne majú tvar tebe, ale $s$ tobu, sobu (pozri Krajčovič 1988, 291). Problematika izoglosy zámenných koreňových morfém tob-, sob- $\|$ teb-, seb- je celkovo trochu zložitejšia (pozri viac Krajčovič 1974, 99-100). Tieto nie nevyhnutne archaické názvy sú teda potenciálne onomastické protiargumenty.

Velmi zaujímavé je naproti tomu v tej istej, Užskej župe, na dnešnej ukrajinsko-slovenskej hranici v blízkosti užsko-sotáckej oblasti, ojkonymum Palad', mad’arsky Palágy, čo je vlastne starobylá tvorba z praslovanského osobného mena Polad so sufixom -jb, čiže ${ }^{\star}$ Poladjb. Dnešné ukrajinské ojkonymum by za praslovanské * dj malo mat $\check{z}$, nie $d$, madarské $g y$ [d'] tiež poukazuje na dentálny element, teda slovenské $d z$. V dokladoch však, a to je mimoriadne dôležité, máme doloženú aj zmenu ${ }^{\star} d j>z$ : Palad 1325, Palaz, Palag 1332 - 1337, Palagh 1436, 1445, Palagy 1436, Polag 1479. J. Stanislav uvádza, že sa tu $d z$ mohlo fakultatívne vyslovit aj ako $z$ a že je to znamenitý doklad (pozri Stanislav 2004, 332); z hladiska hladania pôvodu jazyka Kyjevských listov je možno klúčový, kedže nevieme, či zmena ${ }^{\star} d j>\infty^{\circ}$ je zmenou ${ }^{\star} d j>d z$ alebo ${ }^{\star} d j>z$. Aj preto si trúfame celkovo uzavriet', že onymia tejto oblasti je o niečo viac v súlade s jazykom skúmanej hlaholskej pamiatky ako Panónske kniežatstvo a že hladat pôvod Kyjevských listov na základe toponymie môžeme asi tiež skôr v severnom Potisí ako v okolí Blatenského jazera.

\section{REFERENCES}

Broch, Olaf. 1899. Weitere Studien von der slovakisch-kleinrussischen Sprachgrenze im östlichen Ungarn. Kristiania.

Czambel, Samo. 1906. Slovenská reč a jej miesto v rodine slovanských jazykov. 1. oddelenie: Osnovy a iný materiál rečový. 1. čiastka: Východoslovenské nárečie. Turčiansky Sv. Martin.

Derksen, Rick. 2015. Etymological Dictionary of the Baltic Inherited Lexicon. Leiden - Boston.

Haefs, Hanswilhelm. 2004. Ortsnamen und Ortsgeschichten in Schleswig-Holstein: zunebst Fehmarn, Lauenburg, Helgoland und Nordfriesland. Anmerkungen zur Geschichte. Norderstedt.

Hoops, Johannes. 2003. Reallexikon der Germanischen Altertumskunde. Berlin.

Kortlandt, Frederik. 1980. Zur Akzentuierung der Kiever Blätter. In Zeitschrift für Slavische Philologie 41/1, 1-4.

Kováčová, Viera. 2015. Z problematiky archaizmov v slovenských nárečiach (s osobitným zretelom na sotácke nárečia severovýchodného Zemplína). Ružomberok.

Krajčovič, Rudolf. 1974. Slovenčina a slovanské jazyky I. Praslovanská genéza slovenčiny. Bratislava. Krajčovič, Rudolf. 1988. Vývin slovenského jazyka a dialektológia. Bratislava.

Kroonen, Guus. 2013. Etymological Dictionary of Proto-Germanic. Leiden - Boston.

Lutterer, Ivan - Majtán, Milan - Šrámek, Rudolf. 1982. Zeměpisná jména Československa. Slovník vybraných zeměpisných jmen s výkladem jejich původu a historického vývoje. Praha.

MMFH I. 1966. Magnae Moraviae fontes historici I. 1966. Praha, Brno.

Mócsy, András. 1974. Pannonia and Upper Moesia: a History of the Middle Danube Provinces of the Roman Empire. London - Boston.

Pukanec, Martin. 2013. Svätoplukovo kniežatstvo a stará slovenčina. Nitra.

Pukanec, Martin. 2017. K pôvodu Kyjevských listov z akcentologického hladiska. In Slovenská reč $82 / 2,159-168$.

Schaeken, Joseph. 1987. Die Kiever Blätter. Amsterdam. 
Stanislav, Ján. 1956. Dejiny slovenského jazyka I. Úvod a hláskoslovie. Bratislava.

Stanislav, Ján. 1999. Slovenský juh v stredoveku I. Bratislava.

Stanislav, Ján. 2004. Slovenský juh v stredoveku II. Slovník mien s mapovými prílohami. Bratislava.

Steinhübel, Ján. 2004. Nitrianske kniežatstvo. Bratislava.

Šafárik, Pavel Josef. 1863. Sebrané spisy. Díl II. Starožitnosti slovanské okresu druhého. Praha.

Třštík, Dušan. 2001. Vznik Velké Moravy. Moravané, Čechové a střední Evropa v letech 791 871. Praha.

Varsik, Branislav. 1973. Osídlenie Košickej kotliny II. Bratislava.

\begin{abstract}
SUMMARY: ON THE ORIGIN OF THE KIEV LEAFLETS FROM THE ONOMASTIC POINT OF VIEW. The paper seeks to throw new light on the origin of the Kiev Leaflets by comparing the toponyms in Pannonia and the toponyms in the northern Tisa region. In the northern Tisa region, the Uh-Sotak dialect has been spoken. This dialect seems to be very archaic and able to preserve old linguistic features, including accent. The accent of the Sotak dialect of Koromla, recorded by O. Broch in 1899, is very similar, maybe identical to one in the Kiev Leaflets. Moreover, in the Uh-Sotak dialect we can find all the important phonetic and morphological features of the Kiev Leaflets, such as ${ }^{\star} t j / k t>c,{ }^{*} d j>(d) z,{ }^{*} s k /{ }^{*} s t j>\check{s} \check{c}$, ${ }^{*} d l>l$, epenthetic $l$, roT-, dobrajego $>$ dobraego $>$ dobraago $>$ dobrago, as well as ${ }^{*} j_{b-}>{ }^{*} i$ and then primi/primi, I sg. m. $-\tau m b /-e m b, \mathrm{D}$ sg. teb-, G pl. f. -ach, maybe ${ }^{*} v b c h->v b s-$, and no G sg., A pl. f. of ja-stems -è. The toponyms of the northern Tisa region, such as Zemlin, Zemlyn, Zemlien, Zemlyen, Zemlun, Zemlum 13th - 14th century, Zemlyn Zemlen 15th century, Koromlya 1393, Koromplya $1419<{ }^{\star}$ Kropla, Wensellev $1067<{ }^{\star}$ Vecceslav/Veccilov, Wense 1067 < Vęca < Vętja, Pastukafalva (= Raztuka-)/Rosthoka (= Rozthoka) 15th century, Leveluky $1067<{ }^{\star}$ Levyjě, Haradyscha 1483 (= Hradišče), Palad, Palaz, Palag 14th century $<{ }^{\star}$ Poladjb, and so on, seem to be in accordance with the dialect of the Kiev Leaflets, too. The counter-examples in the region are easy to be explained and not necessarily ancient enough. On the other hand, some of the counter-examples in Pannonia, e.g. villa Priazo, Preaszlef, Preazlo 13th century (cf. Russian Perejaslavlb) or Scerente 1082, Zerenche 13th 14 th century < ${ }^{\star}$ Sręća in the central Zala region, etc., are from the point of view of the Kiev Leaflets dialect inexplicable.
\end{abstract}

Doc. Mgr. Martin Pukanec, PhD.

Constantine the Philosopher University in Nitra

Faculty of Arts

Department of Slovak Language and Literature

Štefánikova 67

94974 Nitra

Slovakia

mpukanec@ukf.sk 